\title{
THE PRESENCE OF ANTI-EBV ANTIBODIES AS THE CAUSE OF FALSE POSITIVE RESULTS IN THE DIAGNOSTICS OF LYME BORRELIOSIS
}

\section{OBECNOŚĆ PRZECIWCIAŁ ANTY-EBV JAKO PRZYCZYNA WYNIKÓW FAESZYWIE POZYTYWNYCH W DIAGNOSTYCE BORELIOZY Z LYME}

\author{
Dorota Plewik $^{1(A, B, C, D, E, F, G)}$, Małgorzata Tokarska-Rodak ${ }^{2(A, B, E, G)}$, Justyna Paszkiewicz ${ }^{2(B)}$
}

${ }^{1}$ Pope John Paul II State School of Higher Education in Biała Podlaska, Innovation Research Centre, Poland

${ }^{2}$ Pope John Paul II State School of Higher Education in Biała Podlaska, Institute of Health Sciences, Poland

Authors' contribution Wkład autorów:

A. Study design/planning zaplanowanie badań

B. Data collection/entry zebranie danych C. Data analysis/statistics dane - analiza i statystyki D. Data interpretation interpretacja danych

E. Preparation of manuscript przygotowanie artykułu F. Literature analysis/search wyszukiwanie i analiza literatury G. Funds collection zebranie funduszy

\begin{abstract}
Summary
Background. Laboratory diagnosis of Lyme borreliosis is based on the detection of anti- $B$. burgdorferi antibodies. Mononucleosis infection can lead to false positive results in serological diagnosis of Lyme borreliosis.

Materials and methods. The experimental group comprised 60 patients diagnosed with Lyme borreliosis and 106 individuals professionally exposed to tick bites, with a positive result of ELISA anti-B. burgdorferi IgM test. The control group consisted of 150 healthy individuals. Immunoassay of antibodies to the Epstein-Barr viral capside antigen (EB-VCA) in the IgM class was carried out by the means of Western blot assay.

Results. In two patients diagnosed with borreliosis the presence of IgM antibodies to EB-VCA was confirmed. In the group of individuals professionally exposed to tick bites and in the control group no anti-EB-VCA IgM antibodies were found.

Conclusions. Anti-EBV IgM antibodies can lead to obtaining false positive results in Lyme borreliosis diagnostics. In the cases when clinical symptoms are not characteristic for Lyme borreliosis, and are accompanied by a positive result of anti- $B$. burgdorferi antibodies assay only in the IgM class, one has to take into consideration the occurrence of cross-reaction in the Western blot test and carry out differential diagnosis with infectious mononucleosis.
\end{abstract}

Keywords: Lyme borreliosis, Borrelia burgdorferi, Epstein-Barr Virus, EB-VCA, Western blot

\section{Streszczenie}

Wprowadzenie. Diagnostyka laboratoryjna boreliozy z Lyme opiera się na wykryciu przeciwciał anty- B. burgdorferi. Wyniki fałszywie pozytywne w diagnostyce serologicznej boreliozy z Lyme mogą być spowodowane mononukleozą zakaźną.

Materiał i metody. Grupę badaną stanowiło 60 pacjentów z potwierdzoną boreliozą z Lyme oraz 106 osób narażonych zawodowo na pokłucia przez kleszcze z pozytywnym wynikiem testu ELISA anty-B. burgdorferi IgM. Grupę kontrolną stanowiło 150 zdrowych osób. Oznaczenie przeciwciał przeciwko antygenowi kapsydowemu wirusa Epstein-Barr (EB-VCA) w klasie IgM wykonano metodą Western blot.

Wyniki. U dwóch pacjentów z potwierdzoną boreliozą stwierdzono obecność przeciwciał IgM przeciwko EB-VCA. W grupie osób narażonych zawodowo na pokłucia przez kleszcze oraz w grupie kontrolnej nie wykazano obecności przeciwciał IgM anty-EB-VCA.

Wnioski. Przeciwciała anty-EBV IgM mogą powodować uzyskanie wyników fałszywie pozytywnych w diagnostyce boreliozy z Lyme. W przypadku gdy objawy kliniczne są mało charakterystyczne dla boreliozy z Lyme i towarzyszy im pozytywny wynik oznaczenia przeciwciał anty- $B$. burgdorferi tylko w klasie IgM, należy wziąć pod uwagę możliwość wystąpienia reakcji krzyżowej w teście Western blot i przeprowadzić diagnostykę różnicową z mononukleozą zakaźną.

Słowa kluczowe: borelioza z Lyme, Borrelia burgdorferi, wirus Epstein-Barr, EB-VCA, Western blot
Tables: 0
Figures: 0

References: 17

Submitted: 28.09 .2015

Accepted: 03.02.2016

Plewik D, Tokarska-Rodak M, Paszkiewicz J. The presence of anti-EBV antibodies as the cause of false positive results in the diagnostics of Lyme borreliosis. Health Problems of Civilization 2016; 10(1): 20-23. DOI: 10.5114/hpc.2016.58204

\section{Background}

Lyme borreliosis is a disease caused by Borrelia spirochetes, in the course of which the skin, joints, the nervous system and heart are infected. In Poland the following types occur: B. burgdorferi sensu stricto (S.s.), B. afzelii, B. garinii, B. valaisiana and $B$. lusitaniae [1]; their reservoirs are free-living animals, mainly rodents, and their vectors are Ixodes spp. ticks. Human infection is the result of foraging a tick attached to the skin, through its saliva or vomit. In the first phase of infection Borrelia

Address for correspondence / Adres korespondencyjny: Dorota Plewik, Innovation Research Centre, Pope John Paul II State School of Higher Education in Biała Podlaska, Sidorska 105, 21-500 Biała Podlaska, e-mail: dorotaplewik@gmail.com, phone: +48 833446904

Copyright: (C) 2016 Pope John Paul II State School of Higher Education in Biała Podlaska. This is an Open Access journal, all articles are distributed under the terms of the Creative Commons Attribution-NonCommercial-ShareAlike 4.0 International (CC BY-NC-SA 4.0) License (http://creativecommons.org/licenses/by-nc-sa/4.0/), allowing third parties to copy and redistribute the material in any medium or format and to remix, transform, and build upon the material, provided the original work is properly cited and states its license. 
burgdorferi sensu lato spread in the skin in the area of bite, usually causing early dermal change in the form of erythema migrans. Rarely, the early stage of the illness takes the form of Borrelial lymphoma. Thereafter the spirochetes ingress to different organs together with blood and lymph. The infection's course can involve arthritis or neuroborreliosis, rarely myocarditis. The patients with Lyme borreliosis who were wrongly diagnosed or were not properly treated can develop acrodermatitis chronica atrophicans, arthritis or irreversible neurological changes. The clinical course of the inflammation may be varied, which makes the proper diagnosis difficult [2]. Diagnosis of Lyme borreliosis in the case of erythema migrans is made on the basis of clinical symptoms, in all other clinical manifestations diagnostic tests are necessary [3]. The basic laboratory test in Lyme borreliosis diagnostics is assessing the level of anti-B. burgdorferi antibodies.

In order to assay the level of specific antibodies, the ELISA immunoenzymatic method, characterized by high sensitivity, is applied. However, in patients suffering from autoimmune diseases and in cases of cross-reaction with antibodies occurring in inflammations caused by other pathogens, false positive results can be obtained. Therefore, implementing a test of high specificity, enabling to detect antibodies to specific B. burgdorferi antigens is necessary. Currently a two-stage system of Lyme borreliosis diagnostics has to be applied. The first stage involves carrying out the ELISA test, and borderline or positive results are confirmed by more specific Western blot (Wb) test. Wb tests used in Lyme borreliosis diagnostics should be characterized by specificity not less than $95 \%$. The most common underlying cause of false positive results is the presence of rheumatoid factor, systemic lupus erythematosus, infection with other spirochetes or infectious mononucleosis $[4,5]$.

Infectious mononucleosis is caused by the Epstein-Barr virus (EBV, Human herpsesvirus 4). The most common symptoms are pyrexia, pharyngitis, tonsillitis, lymphadenopathy, splenomegaly, flu-like symptoms and the presence of atypical lymphocytes in the blood. The infection often involves non-specific symptoms or does not involve any symptoms. In the diagnostics the assay of specific antibodies to capside antigen VCA in the IgM and IgG classes, and to nuclear antigens (aEBNA), as well as to non-specific heterophile antigens is used [6].

Both Lyme borreliosis and infectious mononucleosis can have atypical clinical course, therefore in many cases laboratory tests' results are of key importance. The occurrence of cross-reactions in serological tests, and thereby obtaining false positive results, may lead to wrong diagnosis, and consequently can result in the implementation of unsuitable treatment.

The aim of work was determination of the frequency of anti-EBV IgM antibodies occurrence and their influence on Lyme borreliosis diagnostics.

\section{Materials and methods}

Three groups participated in the study:

- Group I consisted of 200 patients with suspicion of Lyme borreliosis, who were tested with serological diagnostics in the years 2007-2008. The group comprised 90 women aged 24-17, and 110 men aged 21-66. Patients with positive or borderline ELISA test results were tested with the Western blot test during the second stage of Lyme borreliosis diagnostics. From the group of patients who revealed positive results, 60 subjects were randomly chosen and tested with the Wb test including capside antigen EBV (GenzymeVirotech GmbH).

- Group II consisted of 275 persons professionally exposed to tick bites: foresters and farmers from Lublin Voivodeship, 85 women aged 20-64, and 190 men aged 19-86. Blood samples were taken in the years 2012-2013. In all samples anti- $B$. burgdorferi antibodies assay was performed by the means of ELISA test. 106 individuals with positive or borderline ELISA test results in the IgM class underwent $\mathrm{Wb}$ test, involving capside antigen EBV.

- Group III was a control group and comprised 150 healthy individuals, 101 women aged 16-35, and 49 men aged 18-34. Blood samples were taken in the years 2013-2015. All subjects underwent WB test including capside antigen EBV.

In the examinations the Borrelia LINE ImmunoblotIgG/IgM (GenzymeVirotech GmbH) test was applied, which enabled to assay antibodies to the EB-VCA-gp125 antigen in the IgM class as well as to specific antigens $B$. burgdorferi (OspC, VlsE, p39, p83, BBA36, BB0323, Crasp3, pG) in the IgM or IgG classes. The test was carried out according to the manufacturer's recommendations.

The research was approved by the Bioethics Committee of the Medical University of Lublin (No. KE-0254/12/13 and KE-0254/183/2014).

\section{Results}

In the Group I two patients were diagnosed with the presence of IgM antibodies to EB-VCA-gp125. One patient revealed also antibodies to the OspC and the p39 antigens in the IgM class and antibodies to the p39 antigen in the IgG class. The second patient revealed the presence of antibodies to the p39 antigen in the IgM and IgG 
classes. Both in Group II and in the control group no presence of IgM antibodies to EB-VCA-gp125 was found. Data concerning the frequency of occurrence of specific anti-B. burgdorferi antibodies in the groups I and II was published earlier [7, 8].

\section{Discussion}

The tests confirmed the occurrence of cross-reactions while assaying anti-B. burgdorferi antibodies by the means of the ELISA method. The underlying cause of cross-reactions can be other infectious diseases: syphilis, rickettsioses, mononucleosis infection, Cytomegalovirus (CMV), Varicella-zoster virus (VZV) and Herpes simplex virus-2 infections $[9,10]$. In the majority of cases false positive results can be excluded upon the application of the $\mathrm{Wb}$ test $[11,12]$. Even though it is a very rare phenomenon, a false positive result can be obtained in the Western blot method. Goossens et al. examined blood samples coming from 40 patients with diagnosed infectious mononucleosis in order to determine the occurrence of anti-B. burgdorferi antibodies in the IgM class. A positive result in the ELISA method was obtained in 53\% of samples, whereas in the WB test in 35\% of samples positive result for the OspC or the p39 antigen was obtained [13]. In own research involving two patients, who in the $\mathrm{Wb}$ test revealed positive results for IgM anti-B. burgdorferi, anti-EBV IgM antibodies to capside antigen were also present. The results confirm the possibility of cross-reactions between anti-EBV antibodies and specific $B$. burgdorferi OspC and p39 antigens.

Anti-EB-VCA IgM antibodies are present in $95 \%$ of patients infected with EBV during first several days of infection, and then disappear within 2-3 months. Therefore these antibodies can lead to obtaining false positive results in the diagnostics of different diseases only when the infection with EBV took place within the last few months. Such situations happen rarely, which is confirmed by the lack of anti-EB-VCA antibodies in the group of individuals professionally exposed to tick bites and in the control group.

False positive results for anti-B burgdorferi in the IgM class can be obtained also in cases of other viral diseases. Woelfle et al. described a case of an 8-year-old boy with the facial nerve palsy in the course of meningitis and encephalomyelitis caused by Varicella-zoster virus, in whose blood anti-B. burgdorferi antibodies to the OspC and the p41 antigens were present in both ELISA and Wb tests [14]. In the research discussed above Goossens et al. mentiones $21 \%$ of patients with acute Cytomegalovirus infection, who revealed the presence of antibodies to the OspC and the p39 B. burgdorferi antigens [13].

Seriburi et al. in retrospective studies on patients with possible Lyme borreliosis verified the diagnosis basing on the epidemiological and clinical data. $27.5 \%$ of patients were recognized with false positive results for $\mathrm{Wb}$ antibodies assay; in all cases it were IgM [15].

The number of cases of Lyme borreliosis is steadily increasing. According to the National Hygiene Institute (PZH) in 2004 in Poland 3882 cases of Lyme borreliosis were reported, whereas in 2014 the number increased to 13866 cases $[16,17]$. Bearing in mind the frequency of Lyme borreliosis occurrence and the fact that the clinical picture may be diversified, it is extremely important to implement reliable laboratory diagnostics. In questionable cases, especially when the positive result is based only on the occurrence of antibodies in the IgM class, it is important to apply differential diagnostics in order to exclude the possibility of a false positive result. Literature data pointing out that in the first place infectious mononucleosis should be excluded is confirmed by own research. However, one should not forget about other infections, e.g. CMV, VZV, T. pallidum, especially in cases of neuroinfections with dramatical course.

\section{Conclusions}

1. Anti-EBV IgM antibodies can lead to obtaining false positive results in Lyme borreliosis diagnostics.

2. In the cases when clinical symptoms are not characteristic for Lyme borreliosis and are accompanied a by positive result of anti-B. burgdorferi antibodies assay only in the IgM class, one has to take into consideration the possibility of cross-reaction in the Western blot test and carry out differential diagnosis with infectious mononucleosis.

\section{References:}

1. Mączka I, Rogulska U, Tylewska-Wierzbanowska S. Prevalence of Rickettsioses in Poland in 2006-2012. Prz Epidemiol. 2013; 67(4): 721-723.

2. Flisiak R. Borelioza z Lyme In: Cianciara J, Juszczyk J. Choroby zakaźne i pasożytnicze. Wydawnictwo Czelej, Lublin 2012 (in Polish).

3. http://wwwold.pzh.gov.pl/oldpage/epimeld/inne/Def_PL2_3.pdf [cited 2015 Sept 18] (in Polish). 
4. Chmielewski T, Dunaj J, Gołąb E, Gut W, Horban A, Pancewicz S, et al. Diagnostyka laboratoryjna chorób odkleszczowych. Rekomendacje Grupy Roboczej, Warszawa 2014; http://kidl.org.pl/uploads/ rekomendacje/05_kleszcze\%20z\%20okladka.pdf [cited 2015 Sept 18] (in Polish).

5. Flisiak R, Pancewicz S. Diagnostyka i leczenie Boreliozy z Lyme. Zalecenia Polskiego Towarzystwa Epidemiologów i Lekarzy Chorób Zakaźnych. 2011; http://www.pteilchz.org.pl/data/standardy/ borelioza_z_lyme_2011.pdf [cited 2015 Sept 18] (in Polish).

6. Balfour H, Dunmire K, Hogquist K. Infectious mononucleosis. Clinical \& Translational Immunology. 2015; 4: e33. doi:10.1038/cti.2015.1

7. Tokarska-Rodak M, Fota-Markowska H, Śmiechowicz F, Gajownik B, Prokop M, Modrzewska R, et al. Antibodies Against in vivo B. burgdorferi Antigens Evaluated in patients with Lyme Arthritis with Reference to Treatment. Adv Clin Exp Med 2010; 19(4): 489-496.

8. Tokarska-Rodak M, Plewik D, Kozioł-Montewka M, Szepeluk A, Paszkiewicz J. Risk of occupational infections caused by Borrelia burgdorferi among forestry workers and farmers. Medycyna Pracy 2014; 65(1): 109-117.

9. Berardi V, Weeks K, Steere A. Serodiagnosis of early lyme disease: analysis of IgM and IgG antibody responses by using an antibody-capture enzyme immunoassay. J Infect Dis. 1988; 158(4): 754-760.

10. Strasfeld L, Romanzi L, Seder R, Berardi V. False-Positive Serological Test Results for Lyme Disease in a Patient with Acute Herpes Simplex Virus Type 2 Infection. Clin Inf Dis 2005; 41: 1826-1827.

11. Feder H, Gerber M, Luger S, Ryan R. False positive serologic tests for Lyme disease after varicella infection. N Engl J Med. 1991; 325: 1886-1887.

12. Naesens R, Vermeiren S, Van Schaeren J, Jeurissen A. False positive Lyme serology due to syphilis: report of 6 cases and review of literature. Acta Clin Belg. 2011; 66(1): 58-59.

13. Goossens H, Nohlmans M, van den Bogaard A. Epstein-Barr Virus and Cytomegalovirus Infections Cause Folse-Positive Results in IgM Two-Test Protocol for Early Lyme Borreliosis. Infections 1999; $27: 3$.

14. Woelfle J, Wilske B, Haverkamp F, Bialek R. False-positive serological test for Lyme disease in facial palsy and varicella zoster meningo-encephalitis. Eur J Pediatr 1998; 157(11): 953-954.

15. Seriburi V, Ndukwe N, Chang Z, Cox E, Wormser G. High frequency of false positive IgM immunoblots for Borrelia burgdorferi in Clinical Practice. Clin Microbiol Infect 2012; 18: 1236-1240.

16. Czarkowski M, Cielebąk E, Stępień E, Kondej B. Infectious diseases and poisonings in Poland in 2004, Warszawa 2005; http://wwwold.pzh.gov.pl/oldpage/epimeld/2004/Ch_2004.pdf [cited 2015 Sept 22].

17. Czarkowski M, Cielebąk E, Staszewska-Jakubik E, Kondej B. Infectious diseases and poisonings in Poland in 2014, Warszawa 2015; http://wwwold.pzh.gov.pl/oldpage/epimeld/2014/Ch_2014.pdf [cited 2015 Sept 22]. 